\title{
Analisis Niat Kunjungan Kembali Wisatawan Domestik Ke Kota Batam
}

\author{
Dame Afrina Sihombing ${ }^{1}$; Misna ${ }^{2}$ \\ Universitas Internasional Batam, Batam, email : dame@uib.ac.id
}

\begin{abstract}
Abstrak. Pariwisata Kota Batam menjadi salah satu sumber ekonomi selain sektor industri. Jumlah kunjungan wisatawan nusantara Kota Batam tahun 2019 sebanyak 664.645. Penelitian ini memiliki tujuan untuk mencari tahu tentang pengaruh antara citra destinasi, pengalaman, motivasi dan kualitas makanan terhadap niat kunjungan kembali wisatawan domestik ke Kota Batam. Objek dan sampel pada penelitian ini adalah wisatawan domestik yang pernah melakukan kunjungan ke kota Batam. Penelitian ini diteliti dengan menggunakan metode non-probability sampling. Total sampel responden yang akan diuji adalah sebanyak 372 data dengan mengunakan metode statistik yaitu metode regresi berganda. Pengujiaan pada penelitian ini mengunakan IBM SPSS Statistics 24. Hasil uji hipotesis menyatakan bahwa terdapat pengaruh antara citra destinasi, motivasi, pengalaman dan kualitas makanan terhadap niat kunjungan kembali.

Kata Kunci : Niat Kunjungan Kembali, Wisatawan Domestik, Kota Batam
\end{abstract}

Abstract Batam city's tourism is one of the economic revenue besides industrial sector. The number of tourist arrivals in Batam in 2019 was 664,645. This study aimed to find out the impact of destination image, experience, motivation and food quality to tourists revisiting intention to Batam. The object and sample in thisstudy were domestic tourists visited Batam. This study used nonprobability sampling method. The total sample of respondents supporting was 372 data usingstatistical methods, namely multiple regression methods. Data testing in this study used IBM SPSS Statistics 24. The results of hypothesis testing states the destination image, motivation, experience and food quality influence revisiting intention.

Keywords : Revisit Intention, Domestic Tourists, Batam City

\section{A. PENDAHULUAN}

Saat ini, sektor pariwisata pada negara Indonesia menjadi sektor ekonomi yang kuat. Pariwisata merupakan kegiatan perjalanan yang dilakukan dengan adanya jangka waktu dari sebuah tempat ke tempat lain dengan memilki tujuan seperti untuk melaksanakan rekreasi, liburan maupun perjalanan bisnis. Pentingnya sektor pariwisata pada Kota Batam memicu pemerintah untuk meningkatkan kualitas objek-objek pariwisata kota Batam seperti destinasi wisata, akomodasi dan kemudahan akses transportasi.

Untuk memicu datangnya kembali wisatawan ke destinasi wisata terdapat faktor-faktor yang memiliki hubungan pada niat wisatawan untuk berkunjung suatu tempat wisata diantaranya ialah citra destinasi. Citra destinasi merupakan citra tujuan pada pandangan dari semua ilmu, kesan, prasangaka serta perasaan emosional didapatkan oleh seseorang maupun kelompok terhadap objek suatu tempat. Gambar tujuan dibentuk oleh sumber informasi, pengalaman sebelumnya, dan karakteristik wisatawan, contohnya kepribadian 
dan karakteristik demografis (Kim et al., 2015). Dengan adannya nilai positif dalam citra destinasi suatu destinasi wisata pada wisatawan, maka hal tersebut dapat meningkatkan niat turis untuk melakukan kunjungan ke Batam kembali.

Selain dari citra destinasi, pengalaman perjalanan wisata juga penting dalam memicu keinginan wisatawan dalam melakukan kunjungan kembali ke kota Batam. Dengan adanya pengalaman perjalanan yang positif, hal tersebut dapat memberi pandangan kepada wisatawan dalam melakukan kunjungan ke suatu tempat wisata kembali. Chang et al., (2014), jika seseorang puas dan memiliki pengalaman positif dalam sebuah kegiatan, berarti hal itu meningkatkan posibilitas mereka dalam mengulangi kegiatan tersebut.

Dengan adanya pengalaman yang positif dapat memicu juga faktor motivasi wisatawan untuk melakukan kunjungan kembali. Motivasi merupakan aspek yang mendorong wisatawan untuk melakukan perjalanan wisata ke suatu destinasi. Dalam penelitan Khan et al., (2017) Motivasi diartikan sebagai kekuatan internal yang berperan menstabilkan psychological disequilibrium seseorang dengan pengalaman perjalanan. Motivasi perjalanan wisata dapat dibagi menjadi dua yaitu: faktor push dan faktor pull dari motivasi wisatawan untuk meningkatkan niat kunjungan kembali ke suatu destinasi. Dengan adanya penilai positif terhadap ketiga faktor di atas, dapat meningkatkan citra pariwisata di suatu negara.

Selain dari 3 faktor diatas, kualitas dari makanan yang menarik dan bagus dapat meningkatkan kepuasan serta kertarikan seorang wisatawan untuk mengunjungi kembali daerah tersebut. Kualitas makanan merupakan kombinasi antara karakter dari makanan yang memberikan penentuan tingkat penerimaan dari produk dan kualitas makanan yang dapat meninjau ekspetasi dari pelanggan dapat meningkatkan tingkat kepuasan dari tamu. (Christianty et al., 2016).

Negara yang memiliki potensi tinggi dalam bidang pariwisata salah satunya ialah negara Indonesia. Negara Indonesia terkenal dengan negara seribu pulau, dimana terdapat banyak kota maupun pulau yang menjadikan pariwisata sebagai sektor terpentingnya, salah satunya ialah kota Batam. Kota ini merupakan kota yang ada di negara Indonesia yang cukup dikenal sebagai kota industri dan kota pariwisata selain dari Bali. Saat ini, kota Batam sedang mengalami perkembangan yang tinggi dalam sektor pariwisata.

Perkembangan pariwisata di kota Batam semakin meningkat dikarenakan Batam merupakan pulau yang terletak pada wilayah yang strategis karena memiliki jarak yang berdekatan dengan negara tetangga seperti Malaysia dan Singapura. Adanya wisatawan yang datang memiliki tujuannya masing-masing. Adapun tujuan wisatawan dalam melakukan kunjungan ke kota Batam adalah untuk berliburan atau melakukan kegiatan wisata, transit menuju negara lain, mengunjungi kerabat, adanya urusan keluarga maupun melaksanakan perjalanan bisnis serta tujuan lainnya.

Pada data yang tercantum pada gambar diatas, Batam pusat statistik mencatat sebanyak 54.298 wisatawan domestik yang mengunjungi kota batam pada bulan Januari 2019 lalu dan pada akhir tahun 2019 tercatat sebanyak 56.808 wisatawan yang berkunjung. Keseluruhan jumlah kunjungan wisatawan domestik yang tercatat dari awal tahun hingga akhir tahun 2019 adalah dengan jumlah 664.645 wisatawan. 


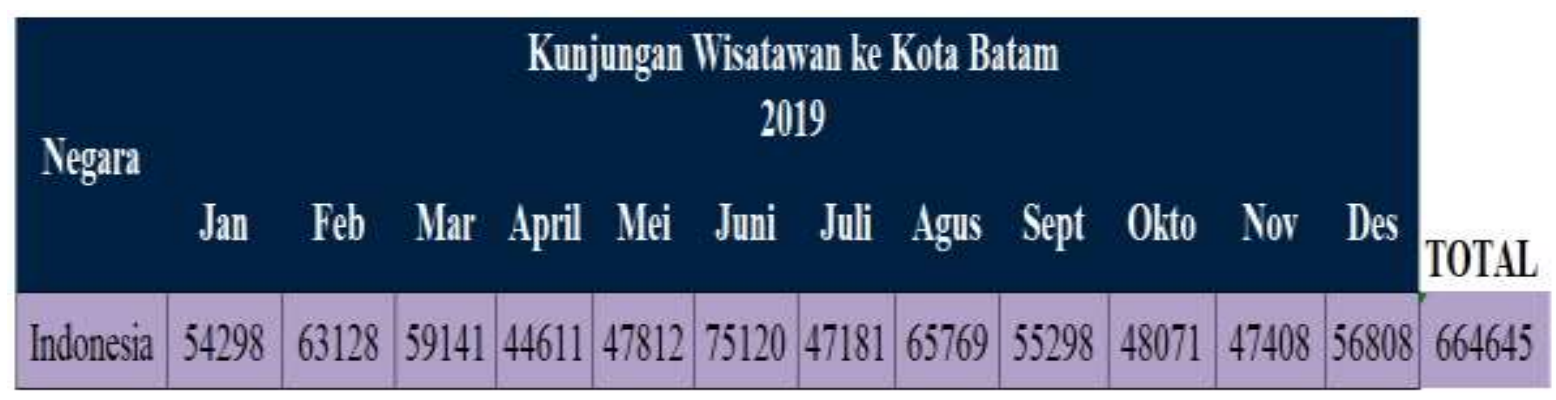

Sumber : Badan Pusat Statistik, 2019

\section{Gambar 1 Data Kunjungan Wisatawan Kota Batam}

\section{B. KAJIAN LITERATUR}

\section{Niat Kunjungan Kembali}

Kunjungan kembali merupakan keinginan pelanggan atau wisatawan untuk melakukan kunjungan lagi ke suatu tempat di masa yang akan datang (S. Kim et al., 2017). Dalam memahami niat munculnya niat untuk melakukan kunjungan kembali pada tempat wisata dapat dipengaruhi oleh faktor - faktor seperti kepuasaan atas kunjungan dulu, pengalaman positif yang didapat tentang tempat wisata tersebut. Akgunduz et al., (2019) emosi positif atau pun negatif yang didapatkan pelanggan dari hasil pelayanan dapat mempengaruhi sikap mereka terhadap jasa pelayanan yang didapatkan dan mempengaruhi positif maupun negatif komentar yang diberikan serta mendapatkan nilai negatif dapat membuat pelanggan untuk tidak berkerjasama atau berkunjung kembali.

\section{Pengaruh Citra Destinasi Terhadap Niat Kunjungan Kembali}

Citra destinasi merupakan perwakilan atau presepsi dari keseluruhan perasaan dan pengetahuan turis terhadap suatu destinasi (Abdullah \& Lui, 2018), citra destinasi mengacu pada ide, kepercayaan dan kesan yang diperoleh oleh individu mengenai karakteristik suatu destinasi (Khan et al., 2017). Dengan adanya impresi bagus wisatawan terhadap citra destinasi akan mengundang atau memicu wisatawan untuk mengunjungi destinasi tersebut.

Pengaruh citra destinasi terhadap niat kunjungan kembali yang telah diteliti oleh (Hasan et al., 2019) menunjukan bahwa citra destinasi memiliki signifikasi langsung pada kepuasan wisatawan, prilaku kunjungan kembali dan kunjungan kembali wisatawan. Hasil penelitian dari M. J. Kim et al., (2015) menyatakan bahwa nilai yang dirasakan dan keluhan yang berasal dari tiga penentu (citra destinasi, motivasi wisatawan dan kualitas persepsi) melalui kepuasan secara signifikan mempengaruhi kunjungan kembali ke tujuan wisata dan berdasarkan penelitian $\mathrm{H}$. Huang et al., (2016) menunjukan bahwa kesesuaian terdapat pengaruh antara citra afektif dan citra kognitif terhadap kepuasan wisatawan dan niat Jurnal Pemasaran Kompetitif, Vol. 04, No. 2 / Februari 2021 
kunjungan kembali. Karakteristik demografis, sikap memiliki pengaruh yang meninjau pada niat kunjungan kembali dan pengalaman pada masa lalu pariwisata maraton mengendalikan relasi antar penyesuaian citra dan kepuasan wisatawan.

Penelitian dari Intan et al., (2018) ditemukan bahwa citra destinasi mempengaruhi kepuasaan keseluruhan wisatawan serta secara analisa regresi linear menyatakan kepuasaan wisatawan memiliki hubungan signifikan positif dengan niat kunjungan kembali. (Purnama \& Wardi, 2019) Citra destinasi memiliki pengaruh dalam niat kunjungan kembali.

\section{Pengaruh Pengalaman Terhadap Niat Kunjungan Kembali}

Pengalaman konsumen terutama terletak pada serangkaian hubungan yang kompleks antara respons subyektif dari pelanggan dan fitur obyektif pada suatu produk. Pada penelitian pariwisata, pengalaman wisatawan selama perjalanan terutama memiliki kaitan dengan mengunjungi, melihat, belajar, menikmati dan menjalani gaya hidup yang berbeda (Chang et al., 2014). Menurut penelitian (F.-H. Chang \& Tsai, 2016) pengalaman merupakan kegiatan yang terdiri dari sensasi perasaan psikologis dan fisiologis, melalui kegiatan partisipasi secara sukarela pada suatu kegiatan pada waktu luang serta individu dapat memperoleh pengalaman sebagai hadiah intrinsik.

Dengan adanya pengalaman kunjungan wisata yang positif atau berkesan dapat memicu wisatawan untuk berkunjung kembali ke suatu destinasi wisata. Terdapat beberapa peneliti yang telah meneliti tentang pengalaman terhadap niat kunjungan kembali diantaranya seperti penelitian (Purnama \& Wardi, 2019) yang menunjukan bahwa pengalaman memiliki pengaruh langsung pada niat kunjungan kembali wisatawan, (Chang et al., 2014) Pengalaman langsung pariwisata adalah yang paling berpengaruh pada niat kunjungan kembali.

\section{Pengaruh Motivasi Terhadap Niat Kunjungan Kembali}

Dalam dunia pariwisata, motivasi digolongkan sebagai kebutuhan psikologis atau biologis yang membangkitkan, mengarahkan serta mengintegrasikan perilaku dan aktivitas individu wisatawan (Khan et al., 2017). Serta menurut (Li et al., 2010) motivasi perjalanan dapat dianggap sebagai factor paling penting dalam memahami perilaku wisatawan dan memungkinkan motivasi perjalanan wisatawan berpengaruh pada niat kunjungan kembali. Dengan adanya motivasi kunjungan perjalanan wisata yang mendorong wisatawan untuk melakukan kunjungan kembali ke suatu destinasi wisata. (Zhang et al., 2019) menyatakan bahwa motivasi wisatawan memiliki pengaruh paling bagus terhadap niat kunjungan kembali.

Li et al., (2010) berdasarkan hasil yang ditemukan dalam penelitian menyatakan variabel motivasi yang mencakup intelektual, kepunyaan dan pelarian memberikan pengaruh yang signifikan pada dimensi citra afektif serta adanya hubungan sebab-akibat yang terindentifikasi antara citra afektif gambar dan niat kunjungan kembali. Khan et al., (2017) menemukan bahwa motivasi perjalanan wanita muda memiliki efek positif pada citra kognitif dan citra afektif serta serta menunjukan bahwa citra kognitif dan afektif secara positif mempengaruhi niat kunjungan calon wisatawan wanita muda.

Penelitian M. J. Kim et al., (2015) menunjukkan bahwa nilai yang dirasakan dan keluhan yang berasal dari tiga penentu (citra tujuan, motivasi wisatawan dan kualitas persepsi) melalui kepuasan secara signifikan mempengaruhi kunjungan kembali ke tujuan 
wisata sedangkan pada penelitian dari (Zhang et al., 2019), pada penelitian ini menunjukan bahwa variabel motivasi wisatawan dan nilai persepsi wisatawan tidak memiliki pengaruh langsung terhadap niat kunjungan kembali wisatawan, tetapi variabel-variabel tersebut dapat mempengaruhi niat mengunjungi kembali melalui pengaruh kepuasan wisatawan.

\section{Pengaruh Kualitas Makanan Terhadap Niat Kunjungan Kembali}

Kualitas makanan didefinisikan sebagai percampuran attribut ataupun karakter produk yang mempunyai arti penting pada suatu produk (Christianty \& Wandebori, 2016). Berdasarkan penelitian (Yusof et al., 2016) yang diklasifikasikan dalam dimensi kualitas pada makanan ialah rasa makanan secara keseluruhan, kesegaran makanan, dan daya tarik mata dari makanan. Dengan adanya imej kualitas makanan yang baik dapat memiliki dampak yang penting dalam kunjungan kembali pelanggan ke suatu tempat.

Penelitian dari Yusof et al., (2016) menunjukkan bahwa kualitas pada makanan yang ditemukan sebagai aspek utama memiliki kontribusi pada niat siswa mengunjungi kembali restoran kopitiam dibandingkan dengan kualitas layanan dan suasana yang baik dari organisasi jasa makanan dan penelitian dari Christianty et al., (2016) menunjukan bahwa adanya hubungan dan pengaruh signifikan dari variabel kualitas makanan dan kepuasaan pelanggan terhadap niat kunjungan kembali ke restoran serta diantara semua variabel hanya kepuasan pelanggan yang paling berpengaruh terhadap niat kunjungan kembali.

\section{B. MODEL PENELITIAN DAN HIPOTESIS}

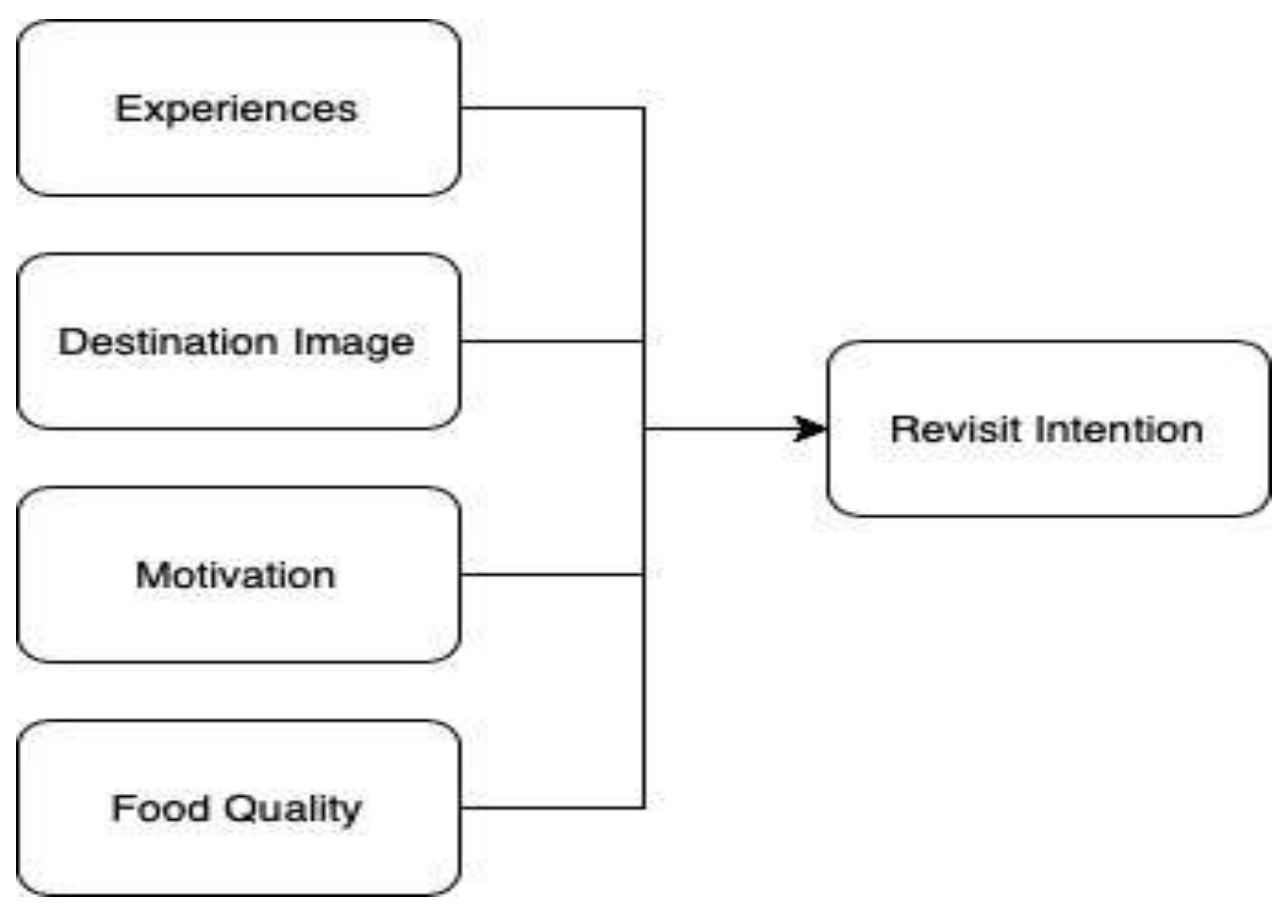

Gambar 2 Model Penelitian

Sesuai dengan model diatas, maka pada penelitian ini dirumuskan:

$\mathrm{H} 1$ : Citra destinasi memiliki pengaruh terhadap niat kunjungan kembali wisatawan domestik ke kota Batam. 
$\mathrm{H}$ 2: Pengalaman wisatawan memiliki pengaruh pada niat kunjungan kembali wisatawan ke kota Batam.

H3: Motivasi turis memiliki pengaruh terhadap niat kunjungan kembali ke kota Batam.

$\mathrm{H} 4$ : Kualitas makanan memiliki pengaruh terhadap niat kunjungan kembali ke kota Batam

\section{METODOLOGI PENELITIAN}

Metode kuantitatif merupakan metode yang memilki sifat untuk melakukan pengujian hipotesis. Penelitian kuantitatif merupakan jenis penelitian dengan menggunakan angka, dimulai dari pengumpulan sampel, pengujian serta hasil dari pengujian (Siyoto \& Sodik, 2015). Penelitian dengan pengujiaan hipotesis yang merupakan fenomena-fenomena dalam hubungan antara setiap variabel. Berdasarkan pada tujuan penelitian, penelitian ini mengunakan hal berkaitan dengan pemecahan masalah yang memiliki sifat teoritis yaitu penelitian dasar.

Berdasarkan pada karakteristik permasalahan penelitian, penelitian ini tergolong dalam penelitian kausal komparatif yang didefinisikan sebagai penelitian yang dilakukan untuk membandingkan objek penelitian antara subjek yang berbeda dan merupakan penelitian sebab dan akibat dalam penyusunan suatu riset metodologi (Siyoto \& Sodik, 2015). Penelitian deskriptif merupakan penelitian yang memberikan gambaran detail mengenai suatu gejala ataupun fenomena (Priyono, 2016).

\section{Objek Penelitian}

Wisatawan domestik atau nusantara ditargetkan sebagai populasi dalam penelitian serta target populasi pada penelitian ini adalah wisatawan domestik yang pernah melakukan kunjungan ke kota Batam. Peneliti melakukan penyebaran kepada 385 responden dan kuesioner yang Kembali dan layak untuk diolah sebanytak 372 . Teknik pemilihan sampel yang digunakan adalah menggunakan jenis non probability sampling, teknik ini adalah proses pengumpulan sampel dengan teknik yang tidak memberi peluang/kesempatan yang sama untuk setiap aspek atau target poulasi yang dipilih sebagai sampel penelitian (Utama \& Mahadewi, 2012).

\section{Variabel Dan Pengukurannya Citra Destinasi}

Citra destinasi merupakan ide, kepercayaan dan pandangan yang diperoleh individu berkaitan dengan karakter destinasi (Khan et al., 2017). Pengukuran pada variabel ini dilakukan dengan 9 pertanyaan yang dikembangkan dari (Song et al., 2017). Jawaban terhadap pertanyaan ini diukur dengan menggunakan skala Likert 5 point (1: sangat tidak setuju, 2: tidak setuju, 3: netral, 4: setuju serta 5: sangat setuju) .

\section{Pengalaman}

Chang \& Tsai, (2016) Pengalaman adalah kegiatan yang terdiri dari sensasi perasaan psikologis dan fisiologis, melalui kegiatan partisipasi secara sukarela pada suatu kegiatan pada waktu luang serta individu dapat memperoleh pengalaman sebagai hadiah intrinsik. Pengukuran variabel ini dilakukan dengan pengembangan 4 pernyataan dari (Tan, 2016). Jawaban responden terhadap 4 pertanyaan ini diukur dengan penggunaan skala Likert 5 poin (1: sangat tidak setuju, 2: tidak setuju, 3: netral, 4: setuju serta 5: sangat setuju). 


\section{Motivasi}

Motivasi dapat diartikan sebagai kekuatan internal yang berperan menstabilkan psychological disequilibrium seseorang dengan pengalaman perjalanan (Khan et al., 2017). Pengukuran pada variabel motivasi ini dilakukan dengan 4 pernyataan dari (Li et al., 2010). Jawaban dari hasil data responden terhadap 4 pernyataan ini diukur dengan menggunakan skala Likert 5 poin (1: sangat tidak setuju, 2: tidak setuju, 3: netral, 4: setuju serta 5: sangat setuju).

\section{Kualitas Makanan}

(Christianty et al., 2016) Kualitas makanan adalah pencampuran pada atribut ataupun karakteristik produk yang memiliki arti penting dalam suatu produk. Pengukuran angket pada 3 pertanyaan yang dikembangkan dari (Yusof et al., 2016). Jawaban responden terhadap 3 pertanyaan pada kuesioner ini diukur dengan skala Likert 5 poin (1: sangat tidak setuju, 2: tidak setuju, 3: netral, 4: setuju serta 5: sangat setuju).

\section{Niat Kunjungan Kembali}

Niat kunjungan kembali merupakan merupakan keinginan pelanggan atau wisatawan untuk melakukan kembali kunjungan ke suatu tempat di masa yang akan datang (S. Kim et al., 2017). Pengukuran variabel dilakukan dengan pengembangan 3 pertanyaan dari (Tan, 2016). Jawaban atas pertanyaan responden terhadap 2 pertanyaan pertama pada variabel ini diukur dengan penggunaan skala Likert 5 poin dengan penerapan (1: sangat tidak setuju, 2: tidak setuju, 3: netral, 4: setuju serta 5: sangat setuju) sedangkan pada pertanyaan lain dengan dengan penggunaan skala Likert 5 poin dengan penerapan rentang 1: sangat setuju, 2: setuju, 3: netral, 4: tidak setuju serta 5: sangat tidak setuju).

\section{Teknik Pengumpulan Data}

Metode kuantitatif merupakan teknik metode yang diterapkan dalam penelitian ini. Metode ini merupakan peneliltian numerik atau berbentuk angka. Pada pengumpulan data yang terkumpul digolongkan sebagai data primer, data primer merupakan sampel data yang dikumpulkan dan diolah sendiri oleh penerbit atau penulis. Data primer penelitian yang digunakan adalah metode survey (kuesioner atau angket pertanyaan), metode ini disebut juga dengan questionere method dikarenakan dalam pengumpulan data dengan mengajukan pertanyaaan yang telah disusun dalam suatu daftar angket (Utama \& Mahadewi, 2012).

\section{Metode Analisis Data}

Penelitian ini diuji dengan menggunakan aplikasi IBM SPSS Statistics 24. Data-data yang terkumpul dianalisis dengan tahapan yang dimulai dari uji statistik deskriptif, uji kualitas data (validitas dan reliabilitas dan uji hipotesis (uji t dan koefisien determinasi). 


\section{HASIL DAN PEMBAHASAN}

Pengumpulan data pada penelitian ini dengan cara penyebaran kuisioner yang layak diuji adalah sebanyak 372 sampel. Penyebaran kuesioner penelitian ini dilakukan dengan penyebaran melalui online melalui media sosial diantaranya ialah instagram, whatapps, line dan wechat serta penyebaran langsung dengan membagikan kuisoner kepada responden. Pengukuran pada karakter responden dengan melalui jenis kelamin, usia, pekerjaan, kota asal, jumlah kunjungan selama 2 tahun terakhir serta tujuan berkunjungan ke kota Batam. Total sampel responden yang layak untuk di uiji adalah sebanyak 372 responden, dengan statistika responden pada tabel-tabel berikut.

\begin{tabular}{|c|c|c|}
\hline \multicolumn{3}{|c|}{ Tabel 1. Statistik Kuesioner } \\
\hline & erangan & Jumlah \\
\hline Kuesioner & ng disebarkan & 385 \\
\hline Kuesioner j & ng tidak layak & 13 \\
\hline Kuesioner & ng layak diuji & 372 \\
\hline \multicolumn{3}{|c|}{ Sumber : Data Diolah, 2020} \\
\hline \multicolumn{3}{|c|}{ Tabel 2. Jenis Kelamin } \\
\hline $\begin{array}{l}\text { Jenis } \\
\text { Kelamin }\end{array}$ & $\begin{array}{c}\text { Jumlah } \\
\text { Responden }\end{array}$ & Persentase \\
\hline Perempuan & 211 & $56,7 \%$ \\
\hline Laki-Laki & 161 & $43,3 \%$ \\
\hline Total & 372 & $100,0 \%$ \\
\hline
\end{tabular}

Berdasarkan data yang ditunjukkan pada tabel diatas menunjukan bahwa dari 372 , responden perempuan lebih mendominasi daripada responden laki-laki dengan total sebanyak 211 (56,7 \%) merupakan responden perempuan, berdasarkan hasil survei yang dilakukan oleh agoda.com dengan tema "well travelled story" menyatakan bahwa sebanyak $72 \%$ perempuan sering melakukan traveling berbeda dengan jenis kelamin laki-laki yaitu sebanyak $65 \%$. Hal inilah yang menjadi alasan responden perempuan yang lebih dominan daripada responden laki-laki.

Tabel 3. Usia

\begin{tabular}{ccc}
\hline Usia & $\begin{array}{c}\text { Jumlah } \\
\text { Responden }\end{array}$ & Persentase \\
\hline 15 - 19 Tahun & 41 & $11,0 \%$ \\
\hline $20-25$ Tahun & 217 & $58,3 \%$ \\
\hline $26-30$ Tahun & 78 & $21,0 \%$ \\
\hline $30-35$ Tahun & 27 & $7,3 \%$ \\
\hline$>36$ Tahun & 9 & $2,4 \%$ \\
\hline \multicolumn{3}{c}{ Sumber : Data Diolah, 2020 }
\end{tabular}

Berdasarkan tabel diatas, menunjukkan bahwa hasil data yang paling mendominasi adalah sampel data pada usia 20-25 tahun mencapai 217 dengan presentase 58,3 \% yang mencapai setengah dari keseluruhan responden, Berdasarkan survei yang dilakukan topdeck travel menyatakan bahwa $88 \%$ dari wisatawan yang melakukan perjalanan wisata 
merupakan anak-anak muda dengan usia 18-31 tahun, hal ini disimpulkan bahwa remaja sekarang lebih sering melakukan kegiatan wisata.

Tabel 4. Pekerjaan Responden

\begin{tabular}{lcc}
\hline Pekerjaan & $\begin{array}{c}\text { Jumlah } \\
\text { Responden }\end{array}$ & Persentase \\
\hline Pelajar & 37 & $9,9 \%$ \\
\hline Mahasiswa & 119 & $32,0 \%$ \\
\hline Wiraswasta & 118 & $31,7 \%$ \\
\hline Karyawan & 73 & $19,6 \%$ \\
\hline IRT & 25 & $6,7 \%$ \\
\hline Total & 372 & $100,0 \%$ \\
\hline \multicolumn{3}{c}{ Sumber : Data Diolah, 2020 }
\end{tabular}

Berdasarkan hasil data yang diisi responden yang terkumpul dapat dilihat bahwa responden yang memiliki pekerjaan yang berbeda-beda, hasil data pada mahasiswa yaitu 119 responden dengan presentase $32,0 \%$. Dalam data hasil kuesioner jumlah status pekerjaan responden yang terbanyak mengunjungi Kota Batam ialah mahasiswa dengan tujuan untuk melakukan kegiatan bisnis, berliburan atau menghilangkkan stres untuk melupakan kegiatan sehari-hari dengan melakukan kegiatan kunjungan ke Kota Batam berdasarkan pada data karakteristik tujuan berkunjung.

Tabel 5. Asal Kota

\begin{tabular}{lcc}
\multicolumn{1}{c}{ Asal Kota } & $\begin{array}{c}\text { Jumlah } \\
\text { Responden }\end{array}$ & Persentase \\
\hline Jakarta & 55 & $14,8 \%$ \\
\hline Surabaya & 14 & $3,8 \%$ \\
\hline Medan & 133 & $35,8 \%$ \\
\hline Pekanbaru & 80 & $21,5 \%$ \\
\hline Asahan & 23 & $6,2 \%$ \\
\hline Jambi & 9 & $2,4 \%$ \\
\hline Panipahan & 9 & $2,4 \%$ \\
\hline Karimun & 15 & $4,0 \%$ \\
\hline Bagan & 5 & $1,3 \%$ \\
\hline Riau & 4 & $1,1 \%$ \\
\hline Bandung & 2 & $0,5 \%$ \\
\hline Tanjung Pinang & 5 & $1,3 \%$ \\
\hline Pontianak & 2 & $0,5 \%$ \\
\hline Selat Panjang & 6 & $1,6 \%$ \\
\hline Tanjung balai & 1 & $0,3 \%$ \\
\hline Malang & 1 & $0,3 \%$ \\
\hline Palembang & 1 & $0,3 \%$ \\
\hline Cianjur & 1 & $0,3 \%$ \\
\hline Padang & 1 & $0,3 \%$ \\
\hline Aceh & 1 & $0,3 \%$ \\
\hline Jogjakarta & 4 & $1,1 \%$ \\
\hline Total & 372 & $100,0 \%$ \\
\hline & Sumber : Data Diolah, 2020
\end{tabular}


Pada tabel asal kota, ditujukan bahwa responden terbanyak merupakan responden yang berasal dari kota Medan sebanyak 133 responden dengan persentasi 35,8\% setelah itu adalah yang berasal dari kota Pekanbaru dengan jumlah 80 responden dengan presentase $21,5 \%$. Responden-responden yang paling banyak terkumpul dari kota Medan dan Pekanbaru, hal ini dikarenakan kedua kota tersebut memilki jarak yang dekat dengan Kota Batam sehingga dapat memudahkan wisatawan untuk melakukan kunjungan.

Tabel 6. Total Kunjungan

\begin{tabular}{lcc}
\hline $\begin{array}{c}\text { Total } \\
\text { Kunjungan }\end{array}$ & $\begin{array}{c}\text { Jumlah } \\
\text { Responden }\end{array}$ & $\begin{array}{c}\text { Persentas } \\
\text { e }\end{array}$ \\
\hline 1 Kali & 134 & $36,0 \%$ \\
\hline 2 Kali & 197 & $53,0 \%$ \\
\hline 3 Kali & 17 & $4,6 \%$ \\
\hline 4 Kali & 14 & $3,8 \%$ \\
\hline$>4$ Kali & 10 & $2,7 \%$ \\
\hline Total & 372 & $100,0 \%$ \\
\hline \multicolumn{3}{c}{ Sumber : Data Diolah, 2020}
\end{tabular}

Berdasarkan tabel total kunjungan responden menunjukan jumlah kunjungan wisatawan yang telah mengunjungi Kota Batam dalam 2 tahun terakhir ini paling mendominasi adalah total kunjungan 2 kali yaitu dengan jumlah 197 responden dengan persentase $55,6 \%$. Berdasarkan viva.com menyatakan wisatawan cenderung mengunjungi suatu lokasi wisata berkali-kali karena terdapat keterikatan emosional, hubungan dekat dengan penduduk lokal, tradisi keluarga serta keindahan pada tempat wisata tersebut.

Tabel 7. Tujuan Kunjungan

\begin{tabular}{lcc}
\hline $\begin{array}{c}\text { Tujuan } \\
\text { Kunjungan }\end{array}$ & $\begin{array}{c}\text { Jumlah } \\
\text { Responden }\end{array}$ & $\begin{array}{c}\text { Persentas } \\
\text { e }\end{array}$ \\
\hline Bisnis & 13 & $3,8 \%$ \\
\hline Liburan & 285 & $76,6 \%$ \\
\hline Transit & 18 & $4,8 \%$ \\
\hline Mengunjungi & 46 & $12,4 \%$ \\
Kerabat & & \\
\hline Urusan Keluarga & 9 & $2,4 \%$ \\
\hline Kuliner & 1 & $0,3 \%$ \\
\hline Total & 372 & $100,0 \%$ \\
\hline
\end{tabular}

Sumber : Data Diolah, 2020

Hasil pengumpulan kuesioner dari responden ini tercatat pada tabel diatas menunjukkan bahwa banyak responden yang melakukan kunjungan ke Kota Batam dengan tujuan untuk berliburan. Pada hasil tercatat bahwa liburan adalah sebanyak 285 responden (76,6\%). Berdasarkan linkadventureindonesia.com, liburan merupakan suatu kebutuhan karena dapat memberikan tenaga, semangat baru, lebih sehat, awet muda, memperluas wawasan, hidup lebih bahagia serta dapat menghilangkan beban pada pekerjaan seharihari. 


\section{Hasil Uji Validitas}

Pada pengujian validitas ini menunjukan bahwa semua pertanyaan pada setiap variabel dinyatakan valid. Hasil uji validitas penelitian ini dapat dilihat dalam tabel dibawah ini:

Tabel 8. Uji Validitas

\begin{tabular}{lcc}
\hline \multicolumn{1}{c}{ Keterangan } & $\begin{array}{c}\text { Pearson } \\
\text { Correlation }\end{array}$ & Kesimpular \\
\hline Citra Destinasi 1 & 0,59 & Valid \\
\hline Citra Destinasi 2 & 0,51 & Valid \\
\hline Citra Destinasi 3 & 0,57 & Valid \\
\hline Citra Destinasi 4 & 0,70 & Valid \\
\hline Citra Destinasi 5 & 0,38 & Valid \\
\hline Citra Destinasi 6 & 0,67 & Valid \\
\hline Citra Destinasi 7 & 0,62 & Valid \\
\hline Citra Destinasi 8 & 0,59 & Valid \\
\hline Citra Destinasi 9 & 0,56 & Valid \\
\hline Pengalaman 1 & 0,60 & Valid \\
\hline Pengalaman 2 & 0,79 & Valid \\
\hline Pengalaman 3 & 0,67 & Valid \\
\hline Pengalaman 4 & 0,79 & Valid \\
\hline Motivasi 1 & 0,72 & Valid \\
\hline Motivasi 2 & 0,70 & Valid \\
\hline Motivasi 3 & 0,67 & Valid \\
\hline Motivasi 4 & 0,76 & Valid \\
\hline Kualitas Makanan 1 & 0,77 & Valid \\
\hline Kualitas Makanan 2 & 0,74 & Valid \\
\hline Kualitas Makanan 3 & 0,77 & Valid \\
\hline Kunjungan Kembali & 0,80 & Valid \\
1 & & \\
\hline Kunjungan Kembali & 0,69 & Valid \\
2 & & \\
\hline Kunjungan Kembali & 0,81 & Valid \\
3 & & \\
\hline
\end{tabular}

Sumber : Data Diolah, 2020

Hasil Uji Reliabilitas

Tabel 9. Uji Reliabilitas

\begin{tabular}{lcc}
\hline \multicolumn{1}{c}{ Variabel } & $\begin{array}{c}\text { Cronbach's } \\
\text { Alpha }\end{array}$ & Kesimpulan \\
\hline Citra Destinasi & 0,75 & Reliabel \\
\hline Pengalaman & 0,68 & Reliabel \\
\hline Motivasi & 0,68 & Reliabel \\
\hline Kualitas Makanan & 0,64 & Reliabel \\
\hline Kunjungan Kembali & 0,65 & Reliabel \\
\hline
\end{tabular}

Sumber : Data Diolah, 2020 
Berdasarkan hasil pengujian ditunjukkan bahwa variabel citra destinasi, pengalaman, motivasi, kualitas makanan dan kunjungan kembali dinyatakan reliabel, hal ini dikarenakan hasil uji menunjukan nilai cronbach's alpha $>0,6$. Oleh karena itu, hasil pengujian pertanyaan antar variabel dinyatakan konsisten.

Uji t

Tabel 10. Uji t

\begin{tabular}{llccc}
\hline Independen & Dependen & Coeficient & Sig & Hipotesis \\
\hline Citra Destinasi & $\begin{array}{l}\text { Niat Kunjungan } \\
\text { Kembali }\end{array}$ & 0,18 & 0,00 & Signifikan \\
\hline Pengalaman & $\begin{array}{l}\text { Niat Kunjungan } \\
\text { Kembali }\end{array}$ & $-0,11$ & 0,04 & Signifikan \\
\hline Motivasi & $\begin{array}{l}\text { Niat Kunjungan } \\
\text { Kembali }\end{array}$ & 0,42 & 0,00 & Signifikan \\
\hline $\begin{array}{l}\text { Kualitas } \\
\text { Makanan }\end{array}$ & $\begin{array}{l}\text { Niat Kunjungan } \\
\text { Kembali }\end{array}$ & 0,14 & 0,01 & Signifikan \\
\hline
\end{tabular}

Sumber : Data Diolah, 2020

Hasil yang ditunjukkan pada uji t menunjukkan bahwa semua hipotesis yang ada pada penelitian menunjukan nilai sig $<0,05$. Pada hipotesis citra destinasi terhadap niat kunjungan kembali dan motivasi pada niat kunjungan kembali menghasilkan nilai sig 0,00 , kualitas makanan pada niat kunjungan kembali dengan nilai sig 0,01 serta nilai sig pada pengalaman terhadap niat kunjungan kembali sebesar 0,04 . Oleh karena itu, semua hipotesis pada penelitian ini dinyatakan memiliki pengaruh signifikan terhadap niat kunjungan kembali.

\section{Uji Koefisien Determinasi (Adjusted $R^{2}$ )}

Hasil pada uji $R^{2}$ ini menghasilkan dalam nilai Adjusted $R^{2}$ adalah sebesar 0,32 dengan arti variabel independen yang tercantum pada penelitian ini dapat menjelaskan $32 \%$ terhadap variabel dependen, serta $68 \%$ lainnya dijelaskan oleh variabel atau faktor lain yang tidak tercantum pada model penelitian ini.

Tabel 11. Uji Koefisien Determinasi

\begin{tabular}{ccc}
\hline $\begin{array}{c}\text { Variabel } \\
\text { Dependen }\end{array}$ & $\begin{array}{c}\mathbf{R} \\
\text { Square }\end{array}$ & $\begin{array}{c}\text { Adjusted } \\
\boldsymbol{R}^{\mathbf{2}}\end{array}$ \\
\hline Kunjungan Kembali & 0,32 & 0,32 \\
\hline Sumber : Data Diolah, 2020
\end{tabular}

\section{KESIMPULAN DAN SARAN}

Pada penelitian memiliki tujuan untuk mennjawab hasil dari setiap pertanyaan variabelvariabel pada kuesioner dan untuk mencari tahu apakah terdapat hubungan antara variabel independen seperti variabel citra destinasi, pengalaman, motivasi dan kualitas makanan terhadap niat kunjungan kembali wisatawan domestik ke Kota Batam. Berdasarkan hasil uji pada hipotesis, penelitian ini memiliki empat hipotesis dan ditemukan bahwa semua hipotesis variabel independen memiliki pengaruh terhadap variabel dependen niat kunjungan kembali wisatawan domestik ke Kota Batam. Pada hasil pengujian ini koefisien determinasi dinyatakan bahwa dalam nilai Adjusted $R^{2}$ menunjukkan hasil sebesar 0,32 artinya variabel independen dapat menjelaskan pada variabel dependen sebesar $32 \%$, 
sedangkan $68 \%$ lainnya dapat dijelaskan oleh variabel atau aspek lain diluar penelitian ini seperti, kepuasan wisatawan, daya tarik wisata dan variabel lainnya.

Bagi peneliti selanjutnya dapat melakukan dan menguji di area lainnya di Indonesia dengan variabel lainnya yang dapat dijelaskan diluar penelitian ini seperti, kepuasan wisatawan, daya tarik wisata dan variabel lainnya. Bagi para pengusaha jasa pelayanan pariwisata dapat meningkatkan kualitas pada masing-masing sektor untuk dapat meningkatkan produk yang ditawarkan kepada wisatawan serta meningkatkan promosi agar wisatawan yang datang dapat mengetahui keunggulan yang dimiliki.

\section{DAFTAR PUSTAKA}

.Abdullah, S. I. N. W., \& Lui, E. (2018). Satisfaction Drivers and Revisit Intention of Internasional Tourist in Malaysia. July, 1-13.

Badan Pusat Statistik. (2019). Data Kunjungan Wisatawan Kota Batam. https://batamkota.bps.go.id/subject/16/pariwisata.html

Cakici, A. C., Akgunduz, Y., \& Yildirim, O. (2019). The impact of perceived price justice and satisfaction on loyalty: the mediating effect of revisit intention. Tourism Review, 74(3), 443-462. https://doi.org/10.1108/TR-02-2018-0025

Chang, F.-H., \& Tsai, C.-Y. (2016). Influence Of The Sports Tourism Attractiveness, Motivation, and Experience On Revisit Intentions. Journal of Social Sciences \& Humanities Research, 961(June), 956-961. https://doi.org/10.1002/da.20578

Chang, L. L., Backman, K. F., \& Huang, Y. C. (2014). Creative tourism: a preliminary examination of creative tourists' motivation, experience, perceived value and revisit intention. International Journal of Culture, Tourism, and Hospitality Research, 8(4), 401-419. https://doi.org/10.1108/lJCTHR-04-2014-0032

Christianty, J., \& Wandebori, H. (2016). Factors Affecting Customer Revisit Intention in Dapoer Pandan Wangi Sunda Resto. 29-34.

Hasan, M. K., Abdullah, S. K., Lew, T. Y., \& Islam, M. F. (2019). The antecedents of tourist attitudes to revisit and revisit intentions for coastal tourism. International Journal of Culture, Tourism, and Hospitality Research, 13(2), 218-234. https://doi.org/10.1108/lJCTHR-11-2018-0151

Huang, H., Lunhua Mao, L., Wang, J., \& Zhang, J. J. (2016). Assessing the relationships between image congruence, tourist satisfaction and intention to revisit in marathon tourism: the Shanghai International Marathon. International Journal of Sports Marketing and Sponsorship, 16(4), 46-66. https://doi.org/10.1108/IJSMS-16-04-2015B005

Khan, M. J., Chelliah, S., \& Ahmed, S. (2017). Factors Influencing Destination Image and Visit Intention Among Young Women Travellers: Role of Travel Motivation, Perceived Risks, and Travel Constraints. Asia Pacific Journal of Tourism Research, 22(11), 1139-1155.

Kim, M. J., Jung, T., Kim, W. G., \& Fountoulaki, P. (2015). Factors affecting British revisit intention to Crete, Greece: high vs. low spending tourists. Tourism Geographies, 17(5), 815-841. https://doi.org/10.1080/14616688.2015.1062908

Kim, S., Park, J. H., Lee, D. K., Son, Y. H., Yoon, H., Kim, S., \& Yun, H. J. (2017). The impacts of weather on tourist satisfaction and revisit intention: a study of South Korean 
domestic tourism. Asia Pacific Journal of Tourism Research, 22(9), 895-908. https://doi.org/10.1080/10941665.2017.1357640

Lesmana, R., \& Hasbiyah, W. (2019). Model Analisis Kepuasan dan Loyalitas Wisatawan Lokal Studi Kasus pada Objek Wisata Kepulauan Seribu Jakarta. JIMF (Jurnal IImiah Manajemen Forkamma), 2(3).

Lesmana, R., Habiyah, W., \& Nabila, N. I. (2020). Peran Kepuasan Wisatawan Terhadap Loyalitas Wisatawan Pada Objek Wisata Kepulauan Seribu Jakarta. JIMF (Jurnal Ilmiah Manajemen Forkamma), 3(2).

Sunardi, N., \& Lesmana, R. (2020). Konsep Icepower (Wiramadu) sebagai Solusi Wirausaha menuju Desa Sejahtra Mandiri (DMS) pada Masa Pandemi Covid-19. JIMF (Jurnal IImiah Manajemen Forkamma), 4(1).

Li, M., Cai, L. A., Lehto, X. Y., \& Huang, J. Z. (2010). A missing link in understanding revisit intention-the role of motivation and image. Journal of Travel and Tourism Marketing, 27(4), 335-348. https://doi.org/10.1080/10548408.2010.481559

Priyono. (2016). Metode Penelitian Kuantitatif (T. Chandra (ed.).

Lesmana, R., Widodo, A. S., \& Sunardi, N. (2020). The Formation of Customer Loyalty From Brand Awareness and Perceived Quality through Brand Equity of Xiaomi Smartphone Users in South Tangerang. Jurnal Pemasaran Kompetitif, 4(1), 1-12.

Purnama, W., \& Wardi, Y. (2019). The Influence of Destination Image , Tourists Satisfaction , and Tourists Experience toward Revisit Intention to The Most Beautiful Village in The World ( Nagari Tuo Pariangan ). 01, 18-25.

Song, H. M., Kim, K. S., \& Yim, B. H. (2017). The mediating effect of place attachment on the relationship between golf tourism destination image and revisit intention. Asia Pacific Journal of Tourism Research, 22(11), 1182-1193. https://doi.org/10.1080/10941665.2017.1377740

Alfiah, S., Andriani, J., Lesmana, R., Sunardi, N., \& Furyanah, A. (2019). Manajemen Pengelolaan Desa Wisata Pada Desa Cimanggu, Kecamatan Cisalak, Kabupaten Subang, Privinsi Jawa Barat (Studi Kasus pada Curug Paok dan Bukit Pasir Jaka). Jurnal Abdi Masyarakat Humanis, 1(1).

Siyoto, S., \& Sodik, M. A. (2015). Dasar Metodologi Penelitian

Tan, W. (2016). Repeat visitation: A study from the perspective of leisure constraint , tourist experience, destination images, and experiential familiarity. Journal of Destination Marketing \& Management, 1-10. https://doi.org/10.1016/j.jdmm.2016.04.003

Utama, I. G. B. R., \& Mahadewi, N. M. E. (2012). Metodologi Penelitian Pariwisata \& Perhotelan (P. Christian (ed.)). CV ANDI OFFSET.

Yusof, N. M., Ibrahim, A. A., Muhammad, R., \& Ismail, T. A. T. (2016). Determinants of UiTM Students' Revisit Intention to Kopitiam in Penang. Procedia - Social and Behavioral Sciences, 222, 315-323. https://doi.org/10.1016/j.sbspro.2016.05.171

Zhang, M., Chen, Q., \& Li, W. (2019). The Influencing Factors and Mechanism of Tourists' Revisit Intention in Chinese Tourism Characteristic Towns-Take Gankeng Hakka Town in Shenzhen as an Example. Journal of Service Science and Management, 12(03), 346-359. https://doi.org/10.4236/jssm.2019.123023 